\title{
RANCANG BANGUN APLIKASI PERENCANAAN PULANG MODEL LIMA BERBASIS WEB
}

\author{
Eka Yulia Fitri ${ }^{1}$, Dhona Andhini' ${ }^{2}$, Dian Wahyuni ${ }^{3}$ \\ 1,2,3 Bagian Keperawatan Fakultas Kedokteran Universitas Sriwijaya \\ Jalan Palembang-Prabumulih, Ogan Ilir, Sumatera Selatan \\ email: ekayulia_01@unsri.ac.id
}

\begin{abstract}
Abstrak
Perencanaan pulang yang efektif mencakup pengkajian berkelanjutan untuk mendapatkan informasi yang komprehensif tentang kebutuhan pasien, pernyataan diagnosa keperawatan, dan perencanaan untuk memastikan kebutuhan pasien yang sesuai. Kesuksesan tindakan perencanaan pulang adalah menjamin pasien mampu melakukan tindakan perawatan lanjutan yang aman dan realistis setelah meninggalkan rumah sakit. Pelaksanaan perencanaan pulang oleh perawat harus dilakukan secara sistematis, terstruktur, dan berkolaborasi multidisiplin antar profesional pemberi layanan kesehatan. Namun, saat ini perencanaan pulang yang dilaksanakan belum maksimal, tidak efektif dan efisien dalam mencapai tujuan pemberian perencanaan pulang bagi pasien. Penelitian ini bertujuan merancang bangun aplikasi perencanaan pulang model LIMA yang dapat membantu perawat dalam memberikan perencanaan pulang bagi pasien. Pengembangan aplikasi berbasis web yang diakses oleh perawat pada saat proses perencanaan pulang. Desain penelitian adalah penelitian rancang bangun mengembangkan aplikasi perencanaan pulang LIMA berbasis web. Melalui aplikasi perencanaan pulang model LIMA berbasis web dapat mempermudah koordinasi dan komunikasi antar profesional pemberi asuhan dalam melakukan perencanaan pulang kepada pasien dan keluarga.
\end{abstract}

Kata kunci: Model LIMA, Perawat, Perencanaan pulang, Rumah sakit, Web

\begin{abstract}
Effective discharge planning includes ongoing assessment to obtain comprehensive information about the patient's needs, statement of nursing diagnoses, and planning to ensure appropriate patient needs. The success of the discharge planning procedure is to ensure that the patient is able to perform safe and realistic follow-up care measures after leaving the hospital. The implementation of discharge planning by nurses must be carried out in a systematic, structured, and multidisciplinary among health care professionals. However, currently the discharge planning has not been carried out optimally, not effective and efficient in achieving the goal of providing discharge planning for patients. The aims of this study was to design a LIMA model of discharge planning application that can assist nurses in providing discharge planning for patients. The research and development design was conducted to develop a web-based application that was accessed by nurses during discharge planning process. Through web-based LIMA model of discharge planning, it could facilitate coordination and communication between professional care providers in planning the discharge planning to patients and families.
\end{abstract}

Keywords: LIMA model, Nurse, Discharge planning, In hospital, Web 
Eka Yulia Fitri, Dhona Andhini, dan Dian Wahyuni, Ruang Bangun Aplikasi Perencanaan Pulang Model Lima Berbasis Web

\section{PENDAHULUAN}

Discharge planning atau perencanaan pulang merupakan kegiatan rutin dalam sistem pelayanan kesehatan yang sudah dilakukan oleh banyak negara dengan tujuan untuk mengurangi lama masa rawat dan perawatan ulang di rumah sakit, serta meningkatkan koordinasi layanan kepada pasien setelah dikeluarkan dari rumah sakit sehingga menjembatani jarak antara rumah sakit dan fasilitas kesehatan di masyarakat (Shepperd, 2013 dalam Fitri, Herliawati, Wahyuni, 2018). Perencanaan pulang merupakan salah satu indikator penentu keberhasilan pelayanan kesehatan di rumah sakit (Nursalam, 2014).

Perencanaan pulang dalam tatanan pelayanan rumah sakit, didefinisikan sebagai proses melalui perawat sebagai koordinator perawatan kesehatan bertanggung jawab terhadap pasien. Perencanaan pulang yang efektif adalah yang efisien, menggunakan standar praktik yang terbaik, melibatkan pasien dan keluarga mulai dari hari pertama dirawat sampai pasien siap dipulangkan ke rumah, serta bersifat inklusif dan menyediakan upaya layanan terkoordinasi dari rumah sakit kepada komunitas di sekitar tempat tinggal pasien (Petitgout, 2015 dalam Fitri, Andhini, Natosba, 2020).

Saat ini, pelaksanaan perencanaan pulang pada pasien di rumah sakit belum dilakukan secara maksimal. Penelitian yang dilakukan di Taiwan menunjukkan bahwa hampir semua pembuat perencanaan pulang adalah staf perawat yang tidak memiliki prosedur evaluasi standar untuk perencanaan pulang, lebih dari tiga perempat pasien menyatakan bahwa rumah sakit menangani rujukan layanan perawatan jangka panjang pasca-keluar secara tidak memadai, dan hingga 94,1\% pasien merasa tidak ada tindak lanjut setelah pulang (Lin, et al., 2013). Sementara di Indonesia perencanaan pulang umumnya hanya berupa catatan resume pasien pulang serta pemberian informasi singkat mengenai jadwal kontrol, penggunaan obat, serta aturan diet setelah pasien pulang dari rumah sakit (Darliana, 2012). Pelaksanaan perencanaan pulang sebagian besar belum dilaksanakan oleh perawat di rumah sakit, dan meskipun telah dilakukan, belum dilaksanakan sesuai dengan standar dan prosedur pelaksanaan (Agustin, 2017).

Hasil penelitian oleh Indriani, Fitri, Hikayati (2016) menunjukkan bahwa $70 \%$ perencanaan pulang baru dilakukan pada saat pasien akan meninggalkan rumah sakit. Perawat tidak melakukan melakukan pengkajian terhadap pengetahuan pasien dan keluarga tentang penyakit yang diderita pasien yang akibatnya memungkinkan pasien tidak mengetahui hal-hal yang harus 
dilakukan setelah pasien pulang (Sagita, Fitri, Kusumaningrum, 2017).

Scott (2010) menyebutkan bahwa kurangnya standarisasi dalam proses perencanaan pulang mempunyai pengaruh terhadap hasil luaran pasien yang buruk, diantaranya adalah penilaian kebutuhan yang tidak memadai, pendidikan dan dukungan pasien dan perawat yang tidak memadai, persepsi yang bertentangan tentang efikasi diri pasien dan pengetahuan kesehatan, kesalahan pengobatan, komunikasi yang buruk dan transfer informasi antar penyedia pelayanan kesehatan, tindak lanjut yang terlewat atau tertunda, dan kegagalan untuk mengatur bantuan rumah dan dukungan komunitas bagi pasien.

Kebijakan perencanaan pulang yang selama ini dijalankan di rumah sakit masih terpisah-pisah, berdiri sendiri, dan tidak terintegrasi sampai pasien kembali ke rumah. Implementasi perencanaan pulang ini belum selaras dengan konsep perencanaan pulang yang menyiapkan pasien dalam masa transisi kembali ke rumahnya, koordinasi perawatan, dan jaminan kontinuitas perawatan meskipun pasien telah kembali ke rumahnya. (Meyers, 2017, Hunter \& Birmingham, 2013 dalam Tage, Novieastari, Suhendri, 2018).

Perencanaan pulang model LIMA merupakan pengembangan model pelaksanaan perencanaan pulang yang dilakukan oleh perawat dengan berkolaborasi dengan profesional kesehatan lain dengan tujuan agar pasien dan keluarga siap untuk melakukan perawatan mandiri setelah pulangdari rumah sakit. Perencanaan pulang model LIMA terdiri dari 4 langkah utama, yaitu: (1) libatkan pasien dan keluarga dalam proses perencanaan pulang; (2) identifikasi kebutuhan perencanaan pulang pasien dan keluarga; (3) metode 3 waktu dalam perencanaan pulang (saat pasien pertama dirawat di rumah sakit, satu hari sebelum pasien pulang, dan saat hari kepulangan pasien); dan (4) analisis dan evaluasi kesiapan pasien dan keluarga (Fitri, Andhini, Natosba, 2020).

Perencanaan pulang model LIMA merupakan bentuk pelaksanaan perencanaan pulang yang terstruktur dan terintegrasi sehingga profesional pemberi asuhan dapat dengan mudah berkomunikasi dan berkoordinasi dalam merencanakan pemulangan pasien. Dalam perencanaan pulang model LIMA implementasi perencanaan pulang dilakukan sejak pasien masuk rumah sakit, pengembangan rencana dikoordinir oleh perawat dan adanya koordinasi antar profesional pemberi asuhan yang disesuaikan dengan kebutuhan pasien, penyediaan layanan pendidikan kesehatan kepada pasien dan keluarga dalam rangka mempersiapkan pengetahuan dan 
Eka Yulia Fitri, Dhona Andhini, dan Dian Wahyuni, Ruang Bangun Aplikasi Perencanaan Pulang Model Lima Berbasis Web

keterampilan keluarga dalam merawat pasien di rumah, dan perawatan yang bersifat kontinyu (Fitri, Herliawati, Wahyuni, 2020).

Perkembangan teknologi informasi khususnya perangkat lunak sudah banyak dikembangkan dalam bidang keperawatan. Teknologi informasi yang dikembangkan bertujuan agar memberikan kemudahan pada perawat dan meningkatkan mutu pelayanan kesehatan (Hamzah, 2016). Namun, pengembangan sistem informasi dan teknologi yang secara khusus mengenai perencanaan pulang dalam bentuk web maupun aplikasi belum banyak dilakukan. Aplikasi ini sangat berguna bagi perawat dan juga tenaga kesehatan lainnya dalam merencanakan pemulangan pasien secara lebih efektif dan efisien.

\section{METODE PENELITIAN}

Desain penelitian ini merupakan penelitian rancang bangun untuk mengembangkan aplikasi perencanaan pulang LIMA yang berbasis website. Perencanaan pulang model LIMA yang telah ada dikembangkan berbasis website karena didasarkan pada kelemahan pada perencanaan pulang model LIMA yang proses pelaksanaannya masih bersifat manual sehingga dibutuhkan waktu yang lama untuk melakukan perencanaan pulang kepada pasien dan keluarga terutama dalam hal koordinasi antar profesional pemberi asuhan dan pelaporan (pendokumentasian) perencanaan pulang.

Website merupakan keseluruhan halaman- halaman web yang terdapat dalam sebuah domain yang mengandung informasi (Astutik, 2018). Metode pengembangan perangkat lunak menggunakan pengembangan perangkat lunak dalam beberapa tahapan System Development Life Cycle (SDLC) atau disebut juga dengan model waterfall. Tahap awal dilakukan analisis permasalahan pada pelaksanaan perencanaan pulang dan mengumpulkan data-data yang relevan dari artikel jurnal serta mengidentifikasi kebutuhan dalam pembuatan aplikasi. Adapun kebutuhan hardware yang dibutuhkan antara lain processor AMD A8 atau setingkat, RAM 2 Gigabytes DDR3, harddisk Drive 500 Gigabytes, peralatan input standar (keyboard dan mouse), monitor (Komputer, Laptop), peralatan jaringan (modem, ethernet Card). Sedangkan software yang digunakan adalah $O S$ Windows/ Mac OS, Browser Google Chromel Mozillal Safari. Bahan penelitian dalam objek penelitian ini adalah berbagai entitas mengenai perencanaan pulang model LIMA, yaitu Pedoman/ Modul Perencanaan Pulang model LIMA. 
Tahap selanjutnya perancangan dan pembuatan aplikasi yang berfokus pada desain software. Langkah pertama adalah dengan merancang desain UML (Unified Modelling Language) yaitu metode dalam pemodelan secara visual yang digunakan sebagai sarana perancangan sistem berorientasi objek. Pada penelitian ini desain UML yang dibuat adalah use case diagram yang mendeskripsikan tipe interaksi antara pengguna sistem dengan sistemnya. Langkah kedua adalah membuat activity diagram yang menggambarkan logika prosedural, proses bisnis, dan jalur kerja dari use case yang telah ditampilkan sebelumnya. Langkah ketiga yaitu membuat class diagram yang menggambarkan hubungan objek-objek yang digunakan dalam sistem ini.

\section{HASIL PENELITIAN}

\section{a. Use Case Diagram}

Pada gambar use case diagram website perencanaan pulang LIMA dijelaskan prosesproses yang terjadi di dalam sistem yang dibuat. Pada use case diagram terdapat dua aktor yang terlibat di dalam sistem. Kedua aktor tersebut berperan sebagai admin dan perawat. Admin sistem adalah pihak yang bertanggung jawab atas maintenance data master pada sistem. Sedangkan perawat bertindak sebagai orang yang dapat melakukan aktifitas seperti melihat informasi tentang pasien dan menginput data pasien.

\section{Hasil Implementasi}

Hasil implementasi menjelaskan penggunaan aplikasi Perencanaan Pulang LIMA berbasis web kepada masingmasing pengguna sesuai dengan fungsifungsi yang dilakukan. Adapun penjelasannya penggunaan aplikasi Perencanaan Pulang LIMA antara admin dan perawat sebagai berikut:

1) Halaman login merupakan halaman awal ketika membuka aplikasi website Perencanaan Pulang LIMA. Baik admin dan perawat harus melakukan proses login terlebih dahulu untuk dapat mengaskses data-data kepentingan perencanaan pulang LIMA (gambar 1).

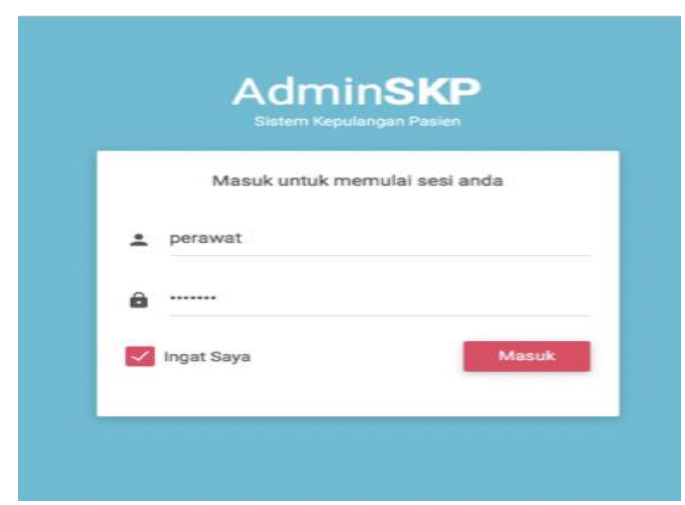

Gambar 1. Halaman Login

2) Halaman home berisi tentang halaman utama saat admin melakukan login (gambar 2).

3) Halaman data posting. Di bagian admin terdapat 2 navigasi di kiri yang berfungsi untuk melihat daftar 
Eka Yulia Fitri, Dhona Andhini, dan Dian Wahyuni, Ruang Bangun Aplikasi Perencanaan Pulang Model Lima Berbasis Web

pengguna dan juga pasien. Daftar

pengguna digunakan untuk melihat orang-orang yang terlibat dalam penggunaan sistem ini sekaligus menjadi data yang akan digunakan dalam sistem (gambar 3 dan 4).

4) Halaman home perawat. Pada bagian ini terdapat daftar pasien yang telah ditambahkan oleh admin (gambar 5).

5) Halaman data pasien. Perawat dapat melihat detail pasien lalu mengisi data pengkajian sesuai dengan urutan dengan mengklik tombol berwarna hijau (gambar 6).

6) Halaman input data pasien. Pada bagian ini perawat dapat mengisi form dengan anjuran dari tenaga kesehatan lainnya yang telah ditentukan dan setelah semuanya terisi data akan terekam ke dalam sistem (gambar 7).

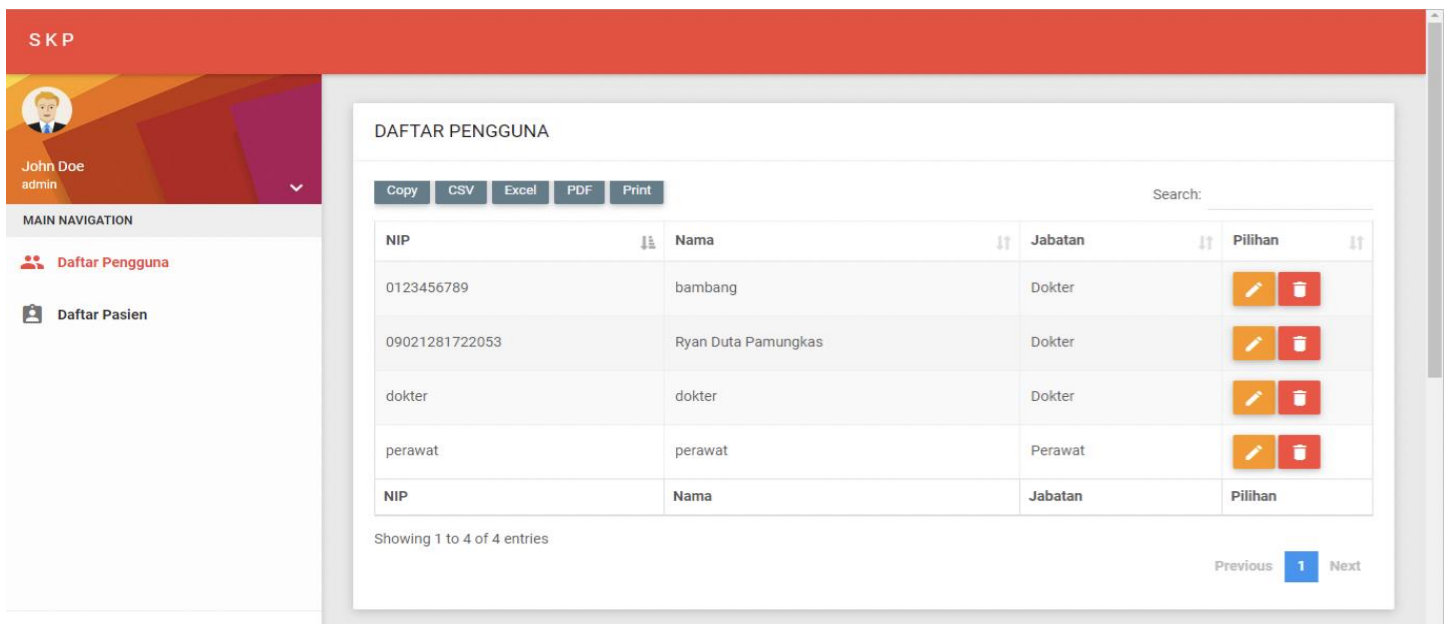

Gambar 2. Halaman home

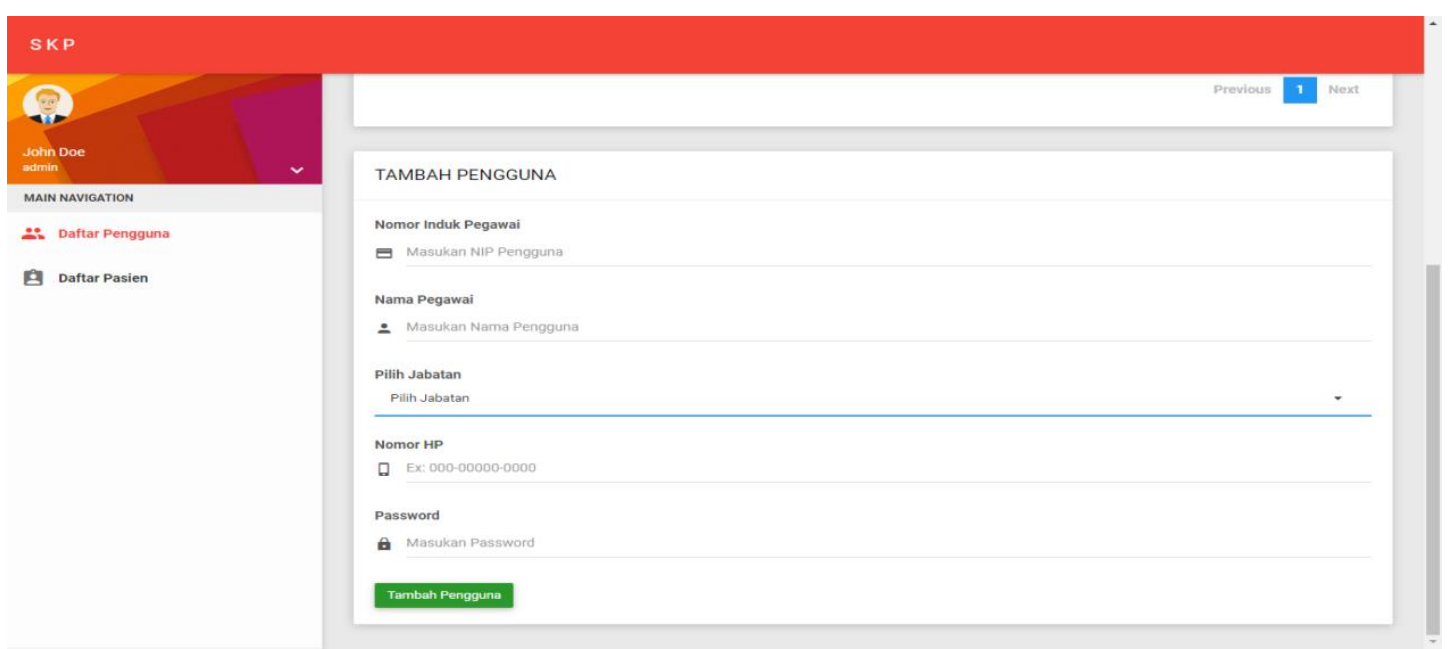

Gambar 3. Halaman Data Posting Tambah Pengguna 
Jurnal Ners Indonesia, Vol.12 No.1, September 2021

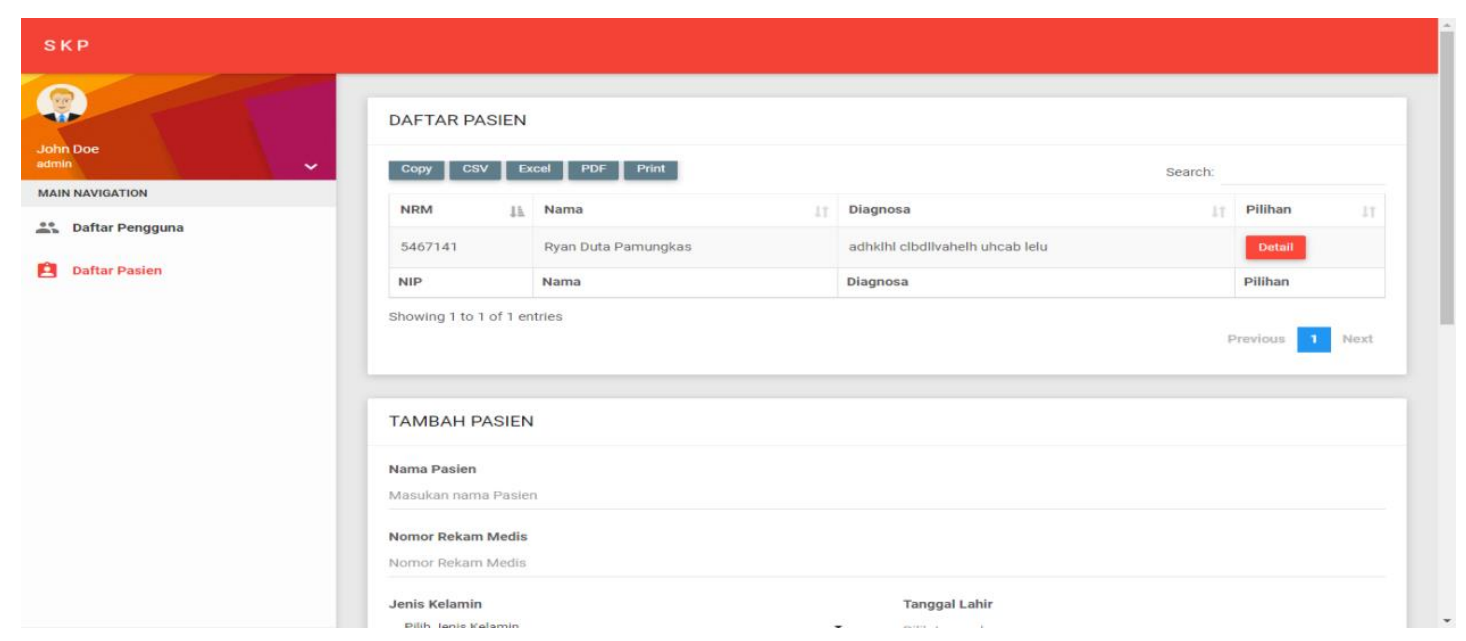

Gambar 4. Halaman Data Posting Tambah Pasien

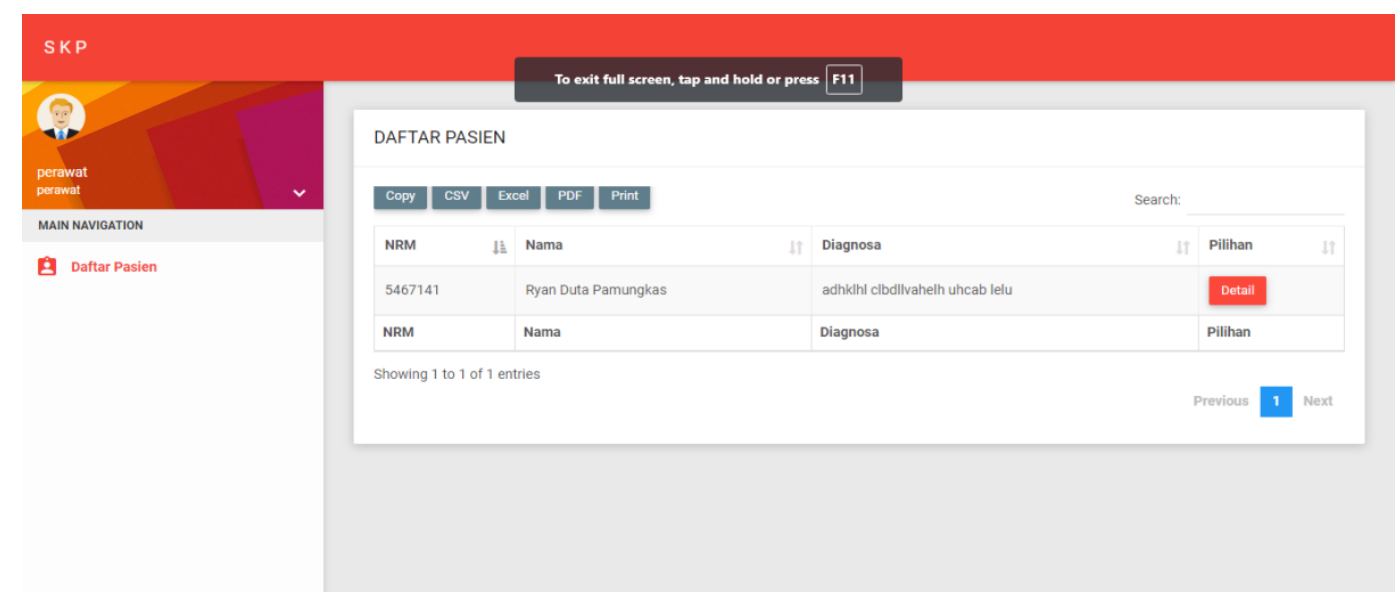

Gambar 5. Halaman home Perawat

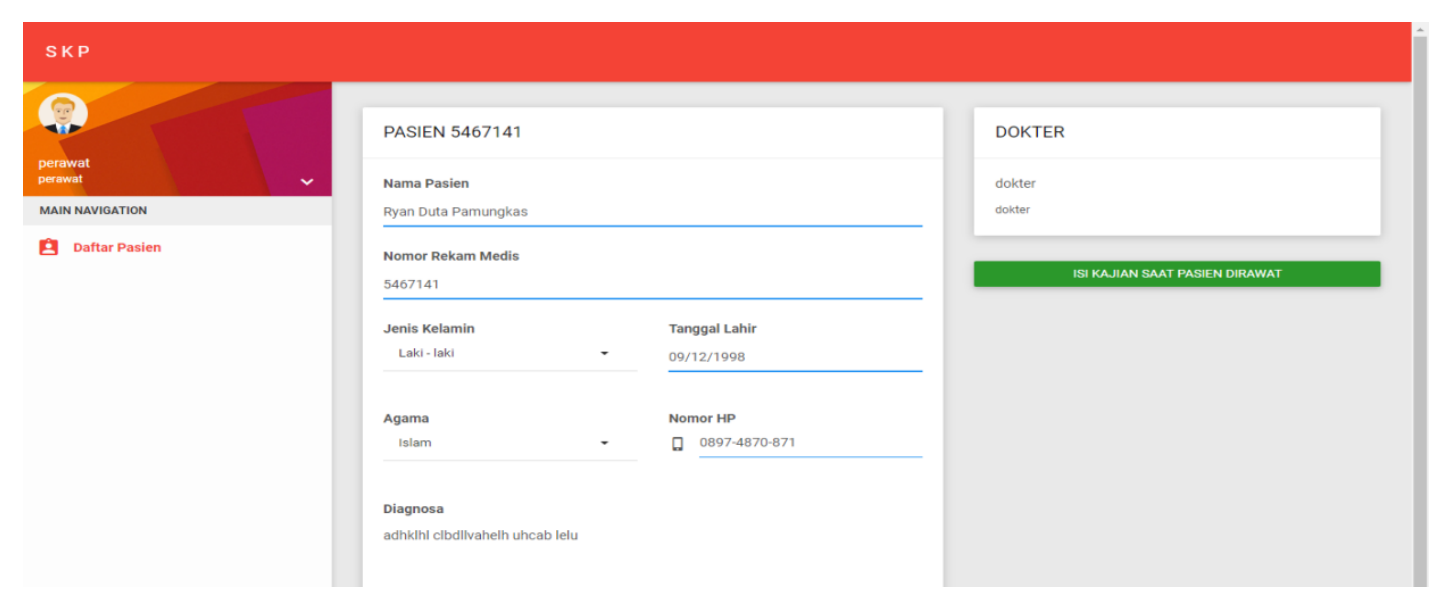

Gambar 6. Halaman Data Pasien 
Eka Yulia Fitri, Dhona Andhini, dan Dian Wahyuni, Ruang Bangun Aplikasi Perencanaan Pulang Model Lima Berbasis Web

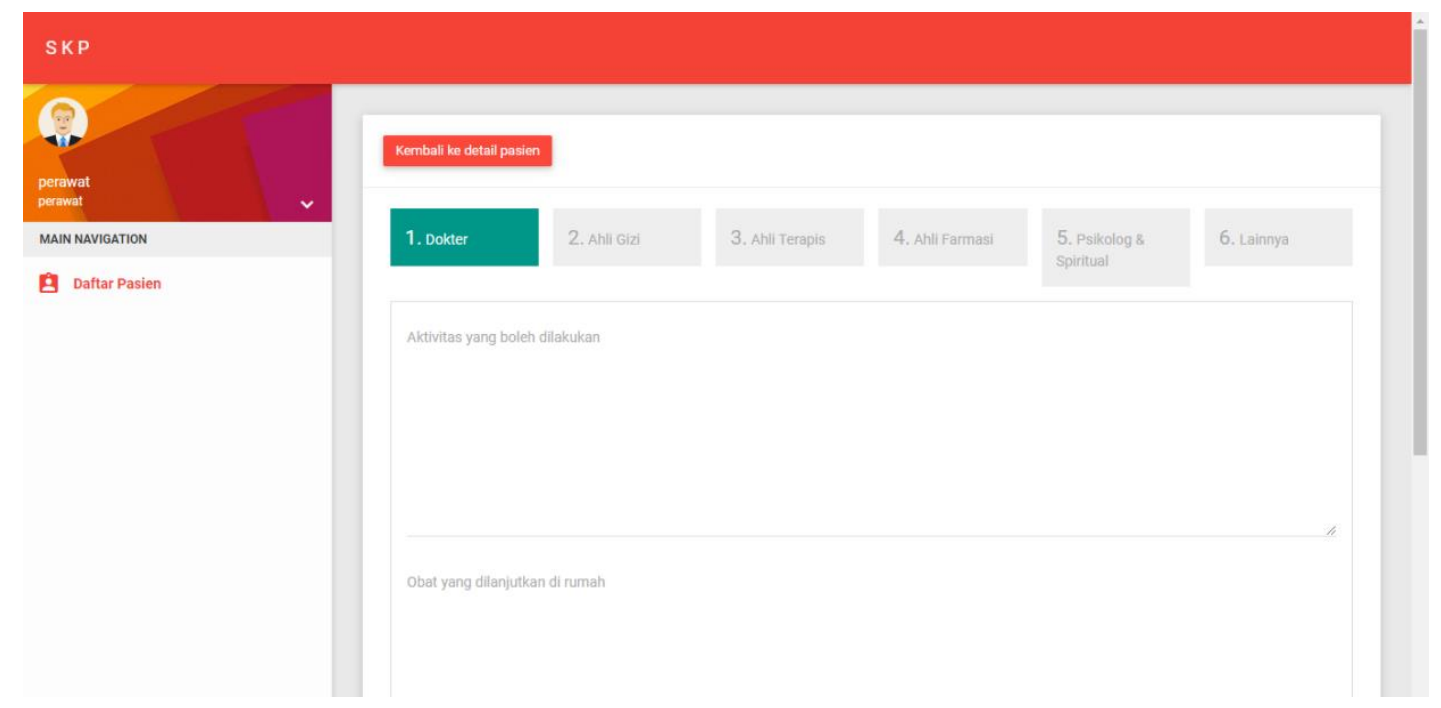

Gambar 7. Halaman Input Data Pasien

\section{PEMBAHASAN}

Hasil penelitian ini didapatkan sistem informasi dan teknologi dalam bidang keperawatan dalam bentuk aplikasi berbasis website yaitu aplikasi Perencanaan Pulang LIMA. Aplikasi ini bertujuan untuk melakukan proses perencanaan pulang oleh perawat yang dimulai dari tahap pengkajian, diagnosa keperawatan, intervensi, implementasi, dan evaluasi, serta pendokumentasian perencanaan pulang sejak pasien baru dirawat di rumah sakit sampai pasien siap untuk dipulangkan ke rumah.

Aplikasi Perencanaan Pulang LIMA berbasis web terdiri dari 10 menu utama, diantaranya 1) program login admin dan perawat, 2) tampilan halaman utama, 3) database pusat data, 4) program tambah pasien, 5) tampilan daftar pasien, 6) program input data pengkajian awal pasien, 7) program input data pengkajian saat/ selama pasien dirawat di rumah sakit, 8) iprogram input pengkajian sehari sebelum pasien pulang, 9) program input saat pasien pulang, dan 10) program konfirmasi pasien siap dipulangkan.

Perencanaan pulang yang baik harus dilakukan mulai dari pasien masuk, selama pasien dirawat di rumah sakit, sampai akhirnya pasien dipulangkan ke rumah. Untuk mendapatkan perencanaan pulang yang berkualitas, perawat harus memiliki pengetahuan dan praktik perencanaan pulang yang baik (Fitri, Andhini, Natosba, 2020). Perencanaan pulang yang dilakukan pertama kali dan dipimpin oleh perawat, dimulai 48 jam setelah pasien datang ke rumah sakit dan didukung oleh tim multidisiplin, dapat mengurangi durasi rawat inap, masuk kembali, dan kematian karena semua penyebab dan biaya rumah sakit (Fox, 
2013 dalam Wulandari \& Hariyati, 2019).

Perencanaan pulang dikatakan berhasil jika dilakukan dengan proses yang terpusat, terkoordinasi, dan di dalamnya terdapat tim multidisiplin yang memberikan kepastian bahwa pasien mempunyai suatu rencana untuk memperoleh perawatan berkelanjutan setelah meninggalkan rumah sakit. Sesuai dengan perkembangan zaman, pengembangan perencanaan pulang dengan menggunakan teknologi perlu dipertimbangkan untuk mewujudkan proses perencanaan yag terpusat dan terkoordinasi. Penelitian oleh Alghamdi \& Taghreed (2016) menunjukkan akan adanya kebutuhan untuk mengembangkan sistem perencanaan pulang yang berdasarkan teknologi, otomatis, dan terkomputerisasi. Temuan utama dari penelitian ini adalah bahwa komputerisasi proses perencanaan pulang menjadi penting karena dianggap dapat meningkatkan komunikasi antara tim perencanaan pulang, akan mempersingkat waktu respons terhadap koordinasi perawatan pasien, dan berpotensi menyediakan laporan instan dari status pasien saat ini yang dapat dilihat oleh semua tim perencanaan pulang pada waktu tertentu. Manfaat menggabungkan sistem seperti ini akan sangat membantu dalam menyederhanakan dan mempercepat proses pemulangan pasien.
Pada aplikasi Perencanaan Pulang LIMA perawat berperan penting dalam membuat perencanaan pulang bagi pasien yang dalam pelaksanaannya sangat memerlukan komunikasi yang efektif, koordinasi antar profesional pemberi pelayanan kesehatan dengan menggunakan website sehingga memudahkan perawat mengakses data dan informasi tentang pasien, dan meningkatkan produktivitas kerja perawat menjadi lebih efektif dan efisien sehingga pelayanan kepada pasien dan keluarga menjadi lebih berkualitas. Peran perawat ini sejalan dengan teori oleh Kozier (2014), Potter \& Perry (2010) dan Nursalam (2014) bahwa perawat mempunyai tanggung jawab utama untuk memberikan instruksi kepada pasien tentang sifat masalah kesehatan, hal-hal yang harus dihindari, penggunaan obatobatan di rumah, jenis komplikasi, dan sumber bantuan yang tersedia.

Kemp, Quan, dan Santana (2017) menyatakan bahwa jika lebih sedikit keterlibatan pasien dalam perencanaan pulang dan tidak ada instruksi tertulis dalam pemulangan pasien maka hal ini akan meningkatkan pasien kembali dirawat di rumah sakit. Sehingga, perawat harus memperhatikan instruksi tertulis dalam pemulangan, jadwal pemeriksaan rutin, dan brosur pendidikan 
Eka Yulia Fitri, Dhona Andhini, dan Dian Wahyuni, Ruang Bangun Aplikasi Perencanaan Pulang Model Lima Berbasis Web

kesehatan yang ditawarkan kepada pasien (Wulandari \& Hariyati, 2019). Aplikasi Perencanaan Pulang LIMA berbasis website yang dikembangkan dalam penelitian mampu menyediakan instruksi tertulis yang harus diketahui oleh pasien dan keluarga dalam perawatan pasien di rumah, bahkan bagi penyelenggara layanan keperawatan di komunitas tempat pasien berada dapat melihat intervensi keperawatan yang sudah dilakukan dan masalah keperawatan yang belum dapat diselesaikan di rumah sakit sehingga perawatan di komunitas dapat memberikan intervensi untuk menyelesaikan masalah keperawatan tersebut.

Penggunaan aplikasi berbasis web seperti aplikasi Perencanaan Pulang LIMA kemungkinan dapat menjadi salah satu solusi untuk meningkatkan implementasi perencanaan pulang di rumah sakit. Pengembangan aplikasi perencanaan pulang LIMA dapat membantu perawat dalam menyusun atau merencanakan perencanaan pulang bagi pasien dan keluarga sehingga pelaksanaan perencanaan pulang dapat terlaksana sesuai dengan tahapan yang sesuai standar dan dapat terciptanya kontinuitas perawatan bagi pasien setelah dipulangkan ke rumah.

Namun, terdapat beberapa keterbatasan dalam pengembangan perencanaan pulang Model LIMA berbasis web ini, yaitu akses untuk masuk ke dalam aplikasi memerlukan jaringan internet (online) dan tampilan website yang masih sangat sederhana, serta keterbatasan dalam hal penggunaan domain yang bersifat temporal karena peneliti menggunakan domain yang berbayar sehingga terbatas pada ketersediaan kuota data pada server dan masa berlaku domain yang harus diperpanjang.

\section{SIMPULAN}

Setelah melalui beberapa tahap perancangan, pembuatan dan implementasi dari hasil penelitian yang sudah dilakukan dapat disimpulkan beberapa hal sebagai berikut:

1. Hasil pengembangan aplikasi menunjukkan bahwa aplikasi dapat diakses melalui komputer, laptop, dan smartphone dengan browser Google Chrome/ Mozilla/ Safari.

2. Aplikasi dapat menampilkan hasil Perencanaan Pulang model LIMA yang dibuat oleh perawat.

\section{SARAN}

Perawat mempunyai perawat yang sangat penting dalam membuat perencanaan pulang bagi pasien. Penggunaan perencanaan pulang yang berbasis teknologi yang efektif dapat digunakan bagi perawat untuk mengoptimalkan pemberian pelayanan perencanaan pulang 
bagi pasien sehingga kontinuitas perawatan pasien tetap berlangsung meskipun pasien telah dipulangkan ke rumah. Selain itu, dengan adanya aplikasi perencanaan pulang berbasis teknologi dapat membantu perawat dalam bekerja secara efisien.

\section{DAFTAR PUSTAKA}

Alghamdi, A.A \& Taghreed, I.J. (2016). Automated Discharge Planning Systems: Perceived Challenges and Recommendations. Health Care: Current Reviews, 2016 4(3). DOI: 10.4172/2375-4273.1000173. Diakses melalui

https://www.researchgate.net/publicati on/309099469

Agustin, R. (2017). Optimalisasi Pelaksanaan Discharge Planning melalui Pengembangan Model Discharge Planning Terintegrasi Pelayanan Keperawatan. Jurnal Keperawatan Muhammadiyah Vol 2 No 1, 2017.

Astutik, A. (2018). Rancang Bangun Aplikasi Rekam Medis Pasien Berbasis Web pada Klinik TS Beauty Centre Bojonegoro. Skripsi. http://repository.dinamika.ac.id/id/epri nt/2857/1/12410100237-2018COMPLETE.pdf

Darliana, D. (2012). Discharge planning dalam keperawatan. Idea Nursing Jurnal. $\quad$ ISSN: 2087-2879. Jurnal.unsyiah.ac.id

Indriani, Y., Fitri., E.Y., Hikayati. (2016). Gambaran Pelaksanaan Discharge Planning Di RSUD Prabumulih. Skripsi tidak dipublikasikan: Fakultas Kedokteran Ilmu Keperawatan Universitas Sriwijaya Indralaya

Fitri, E.Y. (2018). Modul Perencanaan Pulang LIMA. Tidak dipublikasikan.

Fitri, E.Y., Herliawati, \& Wahyuni, D. (2018). Karakteristik, Pengetahuan, dan Pelaksanaan Perencanaan Pulang yang Dilakukan oleh Perawat. Prociding Seminar Nasional Keperawatan Universitas Sriwijaya 2018.

Fitri, E.Y., Herliawati, \& Wahyuni, D. (2020).Pengembangan perencanaan pulang model LIMA. Jurnal Kesehatan Saelmakers PERDANA, 3(2), 186-197.

Fitri, E.Y., Andhini, D., Natosba, J. (2020). Pengaruh discharge planning model lima terhadap kesiapan pulang pada pasien dengan diabetes melitus. Jurnal Kepemimpinan dan Manajemen Keperawatan, 3(1), 15-21

Hamzah. (2016). Rancang bangun sistem informasi asuhan keperawatan bagi penderita pneumonia. Jurnal Sistem Informasi, 8(1), 894-904. http://ejournal.unsri.ac.id/index.php ljsi/index

Kemp, K.A., Quan, H., Santana, M.J. (2017). Lack of Patient Involvement In Care Decisions and not Receiving Written Discharge Instructions are Associated with Unplanned Readmissions up to One Year. Patients Experience Journal, 4(2), 13-22. Diakses melalui

https://pxjournal.org/journal/vol4/is $\mathrm{s} 2 / 4$

Kozier, B., et al. (2014). Fundamentals of nursing: Concepts, process and practice. 1 st volume, 9 th edition. New Jersey: Pearson/prentice Hall.

Lin, S.C., et al. (2013). The past, present, and future of discharge planning in Taiwan. International Journal of Gerontology,7(2013), 65-69. http://dx.doi.org/10.1016/j.ijge.201 3.01.011

Nursalam. (2014). Manajemen keperawatan: aplikasi dalam praktik keperawatan profesional. Edisi 4. Jakarta: Salemba Medika

Potter, PA., \& Perry, GP. (2010). Buku ajar fundamental keperawatan 
Eka Yulia Fitri, Dhona Andhini, dan Dian Wahyuni, Ruang Bangun Aplikasi Perencanaan Pulang Model Lima Berbasis Web

konsep, konsep, dan praktik. Edisi 7. Jakarta : EGC

Sagita, D., Fitri, E.Y., Kusumaningrum, A. (2017). Gambaraan Pelaksanaan Discharge Planning oleh Perawat pada Pasien Stroke di Rumah Sakit Stroke Nasional (RSSN) Bukittinggi. Proceeding Seminar Nasional Keperawatan Program Studi Ilmu Keperawatan Fakultas Kedokteran Universitas Sriwijaya vol 5, nomor 1 Tahun 2019: 9094.http://conference.unsri.ac.id/index. $\mathrm{php} / \mathrm{SNK} / \mathrm{article} / \mathrm{view} / 1632$.

Scott, I.A. (2010). Preventing the rebound: improving care transition in hospital discharge processes. Australian Health Review, 2010, 34, 445451. Diakses melalui www.publish.csiro.au/journals/ahr
Sulastri \& Sari, N.Y. (2018). Metode pendokumentasian elektronik dalam meningkatkan kualitas pelayanan keperawatan. Jurnal Kesehatan, 9(3), 497-502. Diakses melalui http://ejurnal.poltekkestjk.ac.id/index.php/JK

Tage, P.K.S., Novieastari, E., Suhendri, A. (2018). Optimalisasi pelaksanaan discharge planning terstruktur dan terintegrasi. CHMK Nursing Scientific Journal, 2(1), 110

Wulandari, D.F. \& Hariyati, R.T. (2019). The implementation of discharge planning in the general Hospital Jakarta. International Journal of Nursing and Health Services, March 2019, 2(1), 70-81 